\title{
Framväxten av ett nytt samhällsproblem
}

\section{Frågan om positiv propaganda}

I OECD:s högkvarter på 2 rue André Pascal i Paris hölls ett möte 1962 mellan höga representanter för svenskt utbildningsväsende och organisationens speciella byrå Office for Scientific and Technical Personnel. Den fråga som diskuterades var Sveriges förmåga att öka antalet utbildade naturvetare och ingenjörer i framtiden. På bordet framför de församlade låg en rapport - Country Reviews: Sweden - som på ett detaljerat sätt hade bedömt nationens kapacitet under de kommande åren. Rapporten var avsedd att tjäna som inledning till mötet, vars ambition var att de båda parterna tillsammans skulle nå djupare in i problemkomplexet och dess lösning. ${ }^{33}$

Halvvägs in i samtalet frågade den amerikanske representanten Harold Stoke i vilken utsträckning Sverige ägnade sig åt "positiv propaganda" för att locka fler ungdomar till naturvetenskapliga utbildningar. Svaret från den svenska delegationen på plats - bland andra Sven Moberg, avdelningschef på Ecklesiastikdepartementet, universitetskansler Bengt Petri och Frank Öhman, rektor för Överstyrelsen för de tekniska högskolorna - var att även om behovet av fler utbildade naturvetare var uppenbart, kunde lösningen inte vara att utöva påverkan på studenterna. Istället skulle problemet åtgärdas genom en reformering av utbildningssystemet som helhet. ${ }^{34}$

Sammankomsten i Paris bekräftade existensen av ett nytt internationellt problemområde. Runt förhandlingsbordet fanns representanter för hela västvärlden och därtill länder som Turkiet och Jugoslavien. Rapporten om Sverige var på intet sätt unik även om den var den första i sitt slag. Inom ett par år skulle samtliga länder inom OECD ha genomgått liknande utvärderingar. Förfarandet byggde på att experter från andra medlemsländer utförde granskningen, vilket borgade för en opartisk 
TABLE XIV. NEEDS FOR AND SUPPLY OF ENGINEERS AND SGIENTISTS, ACTUAL AND FOREGAST (1950-1975)

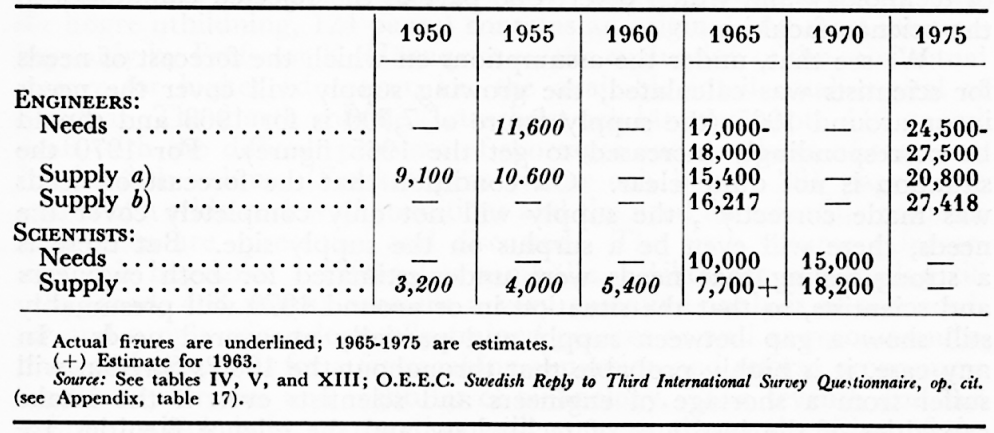

Bild 1. OECD:s bedömning av Sveriges tillgång och efterfrågan på ingenjörer och naturvetare 1950-1975. (Bildkälla: OECD)

bedömning av respektive utbildningssystem. Country Reviews: Sweden var skriven av doktor Vogelnik från universitetet i Ljubljana i Jugoslavien. I en veckas tid hade han rest runt och mött representanter från Ecklesiastikdepartementet, Universitetskanslersämbetet och Skolöverstyrelsen men också träffat personer från de tekniska och naturvetenskapliga forskningsråden $\cdot{ }^{35}$ Rapporten var fylld med tabeller som jämförde tillgång och efterfrågan på ingenjörer och naturvetare vid svenska gymnasier, universitet och tekniska högskolor under 1960- och 1970-talen. På så sätt representerade den en ny typ av utbildningsplanering där långsiktiga prognoser spelade en annan roll än tidigare och där kraven var högre på detaljerad statistik i internationellt standardiserade former om just sådana yrkesgrupper. ${ }^{36}$

Trots att den svenska tillgången på utbildningsstatistik överlag var att beteckna som god, gjorde de detaljerade kraven att det i vissa fall saknades uppgifter. Detta hindrade dock inte doktor Vogelnik från att skissera en rad sannolika händelseutvecklingar. Han konstaterade: "In any case, it is highly probable that throughout the 1960's Sweden will suffer from a shortage of engineers and scientists even if the intake capacities of the institutes of technology and the science faculties are expanded considerably." ${ }^{37}$

Rapporten om Sverige och mötet i Paris är intressanta att ta som utgångspunkter för min studie då de ger tidiga inblickar i hur teknik, naturvetenskap och utbildning fick uppmärksamhet på internationella 
arenor och därigenom antog karaktären av nationsöverskridande angelägenheter. Det innebär inte att problemet var ouppmärksammat inom respektive land. Många nationer, däribland Sverige, hade själva börjat ringa in problembilden. Den inledande formeringen av svensk rekryteringspolitik måste därför förstås som en växelverkan mellan importerade koncept och inhemska förhållanden.

\section{Vetenskapspolitiken och kalla kriget}

Det var knappast någon slump att frågan om positiv propaganda kom från den amerikanske delegaten i OECD:s speciella byrå för naturvetenskaplig och teknisk personal. Ingen annanstans i västvärlden hade behovsbilden under 1950-talet artikulerats så tydligt och resulterat i så stora ansträngningar som i USA, även om utvecklingen i flera andra länder efter hand visade upp ett liknande mönster. ${ }^{38}$ USA:s vetenskapspolitiska ambitioner hade växt i takt med kalla krigets sjunkande temperatur. När nya siffror om det sovjetiska utbildningssystemets kapacitet blev tillgängliga $\mathrm{i}$ mitten av 1950-talet tilltog oron. Harvardprofessorn Nicholas De Witt presenterade 1955 en rapport för kongressen med titeln Soviet Professional Manpower, där han jämförde de båda ländernas produktion av naturvetare och ingenjörer. Resultaten visade att de sovjetiska siffrorna var på väg att gå förbi de amerikanska på fler och fler områden. I en appell till läsarna summerade författaren sina resultat:

[W]e must bear in mind that during the last two and a half decades the Soviet Union has made enormous strides towards building up its specialized manpower resources. As a result of its efforts, it has reached a position of close equivalence with or even slight numerical supremacy over the United States as far as the supply of trained manpower in specialized professional fields is concerned. The Soviet effort continues. Our own policies in the field of education and in regard to specialized manpower resources will decide whether within the next decade or so the scales will be tipped off balance. ${ }^{39}$

Till en början blev det politiska mottagandet av De Witts skrift ljummet. Uppskjutningen av Sputnik i oktober 1957 förändrade dock situationen radikalt. Den sovjetiska satellitens bana över himlavalvet fick konsekvenser på flera plan. Hos den amerikanska allmänheten fästes uppmärksamheten 
nu på det faktum att ledningen i kapprustningen övertagits av den ideologiska fienden. Detta skapade en omvälvning för landets kulturellt rotade självbild som i flera decennier utgått från den egna nationen som teknologiskt ledande. ${ }^{40}$

En mer handgriplig konsekvens av Sputniks uppskjutande var att det frigjorde omfattande ekonomiska resurser till ett undervisningsväsende som fram till dess präglats av decentralisering och misstro mot federala insatser. Denna ordning bröts genom 1958 års National Defense Education Act som gjorde naturvetenskaplig undervisning till en av de viktigaste komponenterna i skapandet av en effektivare vetenskapspolitik. Kalla kriget - som dittills framförallt betraktats som ett militärt fenomen - utökades härigenom med ytterligare arenor där naturvetenskapliga forskare, läroböcker och kursplaner hamnade i centrum. ${ }^{41}$

I kölvattnet av denna förändring utkristalliserades snabbt den unga organisationen National Science Foundation som den huvudsakliga aktören. Tack vare en tredubblad budget 1959 fick den möjlighet att utöka sin verksamhet på flera plan. Under den närmast följande perioden formades två grundläggande komponenter för rekryteringspolitikens fortsatta genomförande. För det första försökte stiftelsen genom det så kallade Scientific Manpower Program skapa tillförlitlig statistik över den faktiska tillgången på naturvetare och ingenjörer, men också med avseende på kommande behov. För det andra initierade den vid sidan av denna visualisering av problemområdet flera olika åtgärder för att skapa fler och bättre utbildade personer inom yrkesgrupperna. Med stipendieprogram till begåvade lärare, doktorander och forskare hoppades man lägga grunden till ytterligare förkovran. Vid sommarläger för lärare skulle äldre undervisningsmetoder fås att försvinna och nyare forskningsrön vinna insteg i skolornas undervisning. ${ }^{42}$

I sin studie av National Science Foundation beskriver Juan Lucena de båda aspekterna av programverksamheten som styrningsteknologier inom den amerikanska policyapparaten. Han menar att programmens funktion dels var att identifiera de delar av befolkningen som redan befann sig inom de önskade yrkesgrupperna, dels att skapa de ytterligare naturvetare och ingenjörer som nationen ansåg sig behöva. ${ }^{43}$ Det ökande bruket av statistik kan förstås som ett sätt för staten att tillfredsställa ett allt större behov av information om sin befolkning, men också som ett sätt att skapa tydlighet gentemot allmänheten och på så sätt stärka legitimiteten i den förda vetenskapspolitiken. ${ }^{44}$ 
Sammanfattningsvis innebar utvecklingen i USA under 1950-talet en betydande förstärkning av ekonomiska medel från staten, vilket skapade utrymme för helt andra initiativ på federal nivå än tidigare. Den kraftiga ökningen av statistik över ingenjörer och naturvetare var också en viktig del av förändringarna, liksom att skolans naturvetenskap placerades $\mathrm{i}$ kalla krigets centrum. Det var från denna nationellt definierade problemhorisont och dess försök till lösningar som Harold Stoke riktade sig till svenskarna vid mötet i Paris.

\section{En europeisk investering}

Närvarande vid sammankomsten på 2 rue André Pascal var också Alexander King, direktör vid byrån för naturvetenskaplig och teknisk personal och tillika en av de ledande europeiska tjänstemännen inom den internationella vetenskapspolitiken. I sina memoarer beskriver han den ökande tilltron till naturvetenskapen och tekniken under 1950-talets andra hälft och de första åren av 1960-talet. Utvecklingen gav löften om att just dessa områden skulle spela helt andra roller för efterkrigstidens samhälle än de hade gjort decennierna före $1945 \cdot{ }^{45}$

Kings redogörelse stöds av de publikationer som OECD gav ut under dessa år. Nya ekonomiska perspektiv gjorde forskning och utveckling inom naturvetenskap och teknik till lämpliga investeringsobjekt för att gynna industriell produktionsökning och tillväxt. Att ekonomiska framsteg inte bara var resultatet av slumpartade och autonoma händelser i historien, utan kunde skapas genom planering och avsiktligt handlande, uppfattades också som ett banbrytande synsätt i samtiden. ${ }^{46}$

OECD (inledningsvis OEEC) utvecklades tidigt till en organisation utan ambitioner att bedriva praktisk politik. Istället arbetade den som en överstatlig sammanslutning med framförallt policyutveckling. I första hand tog den på sig uppgiften att förmå de europeiska industriländernas regeringar att förstå vikten av grundligt utvecklade program och plattformar för en ny vetenskaps- och utbildningspolitik. Granskningarna av olika medlemsländer bör därför inte endast betraktas som utvärderingar, utan också som delar av ett mycket intensivt påverkansarbete för att få till stånd nya sätt att se på sambandet mellan ekonomisk tillväxt, produktionsökning och vetenskap. ${ }^{47}$

Alexander Kings återblickar ger också prov på hur stort inflytande USA hade över det som skedde i Europa efter kriget. Genom Marshallplanen 
och det aktiva deltagandet i utformingen av nya överstatliga organisationer kunde mycket av utvecklingstendenserna inom amerikansk vetenskapspolitik föras över till europeiska förhållanden. Uppskjutandet av Sputnik intensifierade denna utveckling. Bildandet av byrån för naturvetenskaplig och teknisk personal var ett projekt som till hälften finansierades av USA för att öka tillgången på de eftertraktade yrkesgrupperna. King utnämndes till direktör för den nya enheten och rekryteringsfrågan placerades omgående i fokus för arbetet. Ett av byråns första konkreta resultat var sammanställningarna av olika landrapporter, bland vilka Country Reviews: Sweden var ett pionjärprojekt. ${ }^{48}$

Ytterligare ett exempel på ovanstående utveckling är försvarspakten NATO och dess speciella vetenskapliga kommitté, vilken formades i slutet av 1957. Utifrån en identiskt lydande problemdefinition och en mer accentuerad kalla kriget-retorik än i andra sammanhang identifierade organisationen rekryteringsfrågan och behovet av grundforskning som avgörande för västvärldens vetenskapliga utveckling. Genom att finansiera vetenskapliga institut och projekt i medlemsländerna liksom stipendier till doktorander och forskare sökte man tangera och överträffa de uppfattade sovjetiska ansträngningarna. På grund av frånvaron av svenskt deltagande i NATO är dess kommitté dock mer perifer för min studie än OECD:s motsvarighet. Den förstnämnda kommer därför inte att ges mer utrymme i fortsättningen. ${ }^{49}$

Precis som den amerikanska statistiken kan de europeiska ländernas motsvarigheter betraktas som initiala led i en hantering av befolkningens fördelning över olika yrkesgrupper. Det överstatliga perspektiv som OECD anlade möjliggjorde en europeisering av siffrorna. I en studie av forskningspolitikens framväxt på kontinenten pekar policyhistorikern Benoit Godin på att organisationens statistik kom att spela en betydande roll under framförallt 1960-talet. Enligt Godin är det till sådana siffror, serier och tabeller vi måste gå för att förstå hur naturvetenskap och teknik skrevs in som kronjuvelen i den ekonomiska rationalitet som vann så mycket mark under efterkrigstiden. ${ }^{50}$ Utarbetandet av standardiserade definitioner, metoder och koncept manifesterades så småningom i den så kallade Frascatimanualen 1963. Den särställning som naturvetenskap och teknik hade i definitionen av "vetenskap" bekräftas av att manualen fram till sin tredje upplaga 1976 endast mätte utvecklingen inom dessa discipliner. ${ }^{51}$

Förutom att bidra till en kunskapsformering som stärkte relationen 
mellan vetenskap och ekonomisk tillväxt, spelade mätningarna en roll i kraft av sin förmåga att möjliggöra omedelbara jämförelser mellan olika länder. I de alltmer förfinade manualerna kunde man få fram vilka nationer som var att betrakta som föredömliga och vilka som låg sämre till. Godin skriver att mätningarna inte alltid avspeglade de verkliga förhållandena, men att deras viktigaste funktion var förmågan att ge upphov till metaforer som "teknikglapp" mellan nationer och därpå följande "bristdiskurser". ${ }^{52}$ Som helhet ställdes Västeuropa i dålig dager både i relation till Sovjet och USA. King skriver:

For the European countries, the Sputnik shock was even more poignant than for America. We on this continent realized not only the menace of the Russian development, but also how puny our scientific and technical manpower was compared to that of America. It was imperative that Europe make strong efforts to expand its scientific research and technological development. ${ }^{53}$

Detta dubbla mindervärdeskomplex gav ytterligare anledningar till mer renodlade initiativ för att "europeisera" vetenskapen. Det tydligaste uttrycket för detta var insatserna för utbildning och den förändrade uppfattningen om betydelsen av naturvetenskap i skolan.

\section{Utbildningens ekonomisering}

Rapporter av typen Country Reviews: Sweden vilade inte bara på övertygelsen om vetenskapens allt större betydelse för tillväxt och produktionsökning. Nya ekonomiska teorier tillmätte även utbildning sådan betydelse. Enligt den moderna humankapitalteorin, som presenterades av nationalekonomen Theodore W. Schultz 1960, borde lärande och utbildning inte endast betraktas som konsumtion utan också som ekonomiska investeringar. ${ }^{54}$ Schultz resonemang hängde samman med en innovation $i$ synen på tillväxt vid samma tid. Bland ekonomer vid universitet och inom statsförvaltningar spreds uppfattningen att det inte räckte att ta hänsyn till de klassiska faktorerna arbete och kapital för att förstå fenomenet. Man riktade alltmer uppmärksamhet mot kunskap och utbildning för att ringa in en tredje faktor, den så kallade "residualfaktorn". ${ }^{55}$ Den gjorde gällande att arbetskraftens kvalitet, främst graden av skolning, hade spelat en stor roll för tillväxten efter kriget. Ekonomhistorikern Lars Pettersson skriver: 
"En satsning på utbildning kunde därmed betraktas som tillväxtskapande samhällelig investering to m betydelsefullare än fysisk kapitalbildning." ${ }^{\prime 5}$ Perspektivet utvecklades under de följande åren inte minst inom OECD. Genom uttrycket economics of education markerades den nya synen på utbildningens inneboende kvaliteter - som en följd började de ekonomiska vinsterna med en skolad befolkning lyftas fram vid sidan av de sociala och politiska fördelarna. ${ }^{57}$

De nya perspektiven blev under 1950- och 1960-talen tydligast i samband med utbildningen av naturvetare och ingenjörer. Även här blottlade OECD:s samarbete med USA betydande skillnader. Kings memoarer understryker detta:

The educational disparities between the two parts of OECD [USA och Västeuropa] were dramatically wide, whether measured by the proportion of students entering higher education, numbers of degrees awarded or numbers of engineers. Educational expansion in Europe had been rapid since the war, so the demonstration of an educational gap was a shocking, if salutary, revelation. It was now generally assumed that the future economy would be powered by technology, so the provision of a greatly strengthened corpus of scientists and engineers was paramount - catching up with the Russians now switched to catching up with the Americans! ${ }^{58}$

Övertygelsen om att rekrytering hängde samman med förändringar av undervisningen i dessa ämnen ledde till en omfattande satsning på att förnya läroplanerna för många av medlemsländerna. Initiativet hade inspirerats av de omfattande amerikanska undervisningsreformerna under 1950-talet. Med projektet "New Thinking in School Science" riktade sig OECD till utbildningsministrarna i Europa. Sammanlagt tio skrifter i ämnena matematik, fysik, kemi, biologi och teknik utarbetades under åren 1960-1965 och tillsammans med en serie konferenser och rapporter var de tänkta att skapa nya strukturer för enrollering inom de europeiska utbildningssystemen. Projektet rymde radikala förslag på förändringar av undervisningsmaterialet, lärarutbildningen och industrins roller samt ett mer aktivt sökande efter naturvetenskapliga begåvningar. ${ }^{59}$ Vid ett seminarium om kemiämnet 1960 i Greystones på Irland konstaterade ordföranden, professor T.S. Wheeler, i sitt inledningsanförande: 
Of the importance of this Seminar, I need say little. This is an age of science. It is becoming essential that those who leave our schools should have some general knowledge of the content of modern science. But this is only part of the story: the prosperity of a country increasingly correlates with the number of scientists and technologists it employs and these can be produced only if there is adequate training in basic science in the schools. A growing shortage of such scientists and technologists has, over recent years, been a source of concern to those concerned with the governing of men, and much thought is now given to remedying to this defect. ${ }^{60}$

Policyuttalanden av detta slag möjliggjorde en ny typ av problembeskrivning. Tillsammans med den snabbt växande statistiken och uppfattningen om att Europa var underlägsna supermakterna bidrog den till att identifiera nya föremål för liberalt styre, nämligen skolelever och deras förhållande till naturvetenskap och teknik som utbildning, yrke och identitet.

Formuleringarna i Greystones visade också - i likhet med Kings situationsbeskrivning av den europeiska självuppfattningen - att kulturellt formade självbilder inte behövde följa nationsgränserna såsom den amerikanska vetenskapspolitiken hade gjort. Europeiseringen av rekryteringsfrågan innebar att stora delar av kontinenten nu anmodades att sträva efter en gemensam utgångspunkt. I sitt anförande fastslog professor Wheeler: "In general our aim must be to give those with the required talent a desire to make science - pure or applied - their life-work." ${ }^{11}$ I förlängningen av sådana uttalanden var det en nödvändighet att förändra det sätt på vilket många ungdomar såg på sig själva och sin framtid.

Det gemensamt skisserade projektet skulle dock snart stanna av på policystadiet i enlighet med OECD:s beslut om att inte bedriva praktisk politik. Därför blev de internationella sammankomsterna och deras resultat endast rekommendationer till de olika regeringarna. Det europeiska anslaget försvårades också av att de enskilda länderna bedömdes ha kommit olika långt i utvecklingen, något som krävde anpassade strategier, tilltal och resurser. ${ }^{62}$ Projektet var därför, ju närmare man kom respektive lands undervisningspraktiker, inte så gemensamt som den visionära retoriken lät påskina. När satsningen på "New Thinking in School Science” slutförts skulle ansvaret att föra målsättningen vidare successivt komma att föras över på de enskilda länderna. 


\section{"Så kallad 'science policy"”}

När ecklesiastikminister Ragnar Edenman i början av 1963 intog talarstolen i Wenner-Gren Centers nya lokaler vid Sveavägen hade åhörarna redan lyssnat till några av de främsta vetenskapsföreträdarna i landet. Konferensen Vetenskapen i framtidens samhälle hade bland andra samlat fysikern Torsten Gustafson, biokemisten Arne Tiselius och medicinaren Bror Rexed för att kasta ljus över de snabba förändringar som skedde inom deras respektive discipliner. Därtill hade en representant för industriforskningen, Sven Brohult, talat om utvecklingstendenser inom den svenska produktionsindustrin. ${ }^{63}$

Edenmans anförande utgick från politikernas syn på de utmaningar som uppstått till följd av forskningens snabba tillväxt. Expansionen var oerhörd inte bara i intellektuellt avseende utan också sett till det antal individer och kvadratmeter som den tog i anspråk. Vad denna utbredning av vetenskapssamhället innebar och hur den skulle motiveras, menade statsrådet, behövde kommuniceras till samhället på ett mer markerat sätt än tidigare. Han tryckte på behovet av en "så kallad 'science policy". ${ }^{64}$ Begreppsimporten röjde att inte bara uttrycket som sådant var nytt. Själva tanken på att skapa en plattform för mer långsiktig och prioriterad forskningspolitik innebar en upprustning jämfört med perioden före kriget. I regeringens nyligen inrättade forskningsberedning hade man året innan sökt åstadkomma just sådana förhållanden där kontakten mellan politiker och forskare skulle förtätas. Beredningen skulle följa den vetenskapliga utvecklingen och ta beslut som var avsedda att gälla på lång sikt. Både konferensen och beredningen underströk den starka dominansen av naturvetenskap och teknik - humaniora, samhällsvetenskap och ekonomi fanns företrädda i de publikationer och rapporter som följde, men var snarast undantag som bekräftade regeln. Med tanke på att det var forskningsberedningens huvudaktörer och innersta krets som framträdde på Wenner-Gren Center är det lätt att beskriva konferensen som svensk vetenskapspolitik förkroppsligad. ${ }^{65}$

Tillfället kan också betraktas som en kulmen på den tidiga efterkrigstidens starka teknik- och utvecklingsoptimism. Regeringen hade redan på 1940-talet tagit initiativ till bildandet av forskningsråd inom naturvetenskap och teknik. Statsminister Tage Erlanders personliga engagemang för forskningens villkor och hans nära kontakter med en liten grupp vetenskapsutövare ledde till att dessa frågor tillhörde de mer prioriterade politiska områdena under de första decennierna efter 
kriget. Mellan 1960/61 och 1969/70 ökades de statliga anslagen till det tekniska forskningsrådet med 765 procent (5,2 miljoner kronor till 45 miljoner kronor) medan det naturvetenskapliga forskningsrådet under samma tid ökade med 528 procent (5,8 miljoner kronor till 36,4 miljoner kronor). Sammankomster i Harpsund mellan regeringen och forskarna skapade en ömsesidig tro på varandras budskap; politikerna smittades av akademikernas optimism samtidigt som de senare fick löften om ökade resurser för sin verksamhet. ${ }^{66}$

Socialdemokratins dominerande position i samtiden är nödvändig att dröja vid. Partiet var drivande i att formulera välfärdspolitiken men också inledningsvis framgångsrikt i sina föresatser att slå mynt av tidens teknikoptimism. Tilltron till vetenskapens möjligheter var mycket stor under 1950-talet och delar av 1960-talet. År 1956 gav partiet ut boken Framstegens politik och i inledningen hette det:

Den politiska debatten inom arbetarrörelsen präglas av medvetandet om de möjligheter till snabba framsteg som den tekniska och vetenskapliga utvecklingen erbjuder. Den hämtar styrka och stimulans ur tillförsikten om socialdemokratins förmåga att leda denna utveckling mot ökad frihet och trygghet för den enskilda människan. ${ }^{67}$

Visionerna om teknikens välståndsbringande kraft gjordes på så sätt till delar av partiets ideologiska plattform. Teknikoptimismen blev därigenom - tillsammans med den exceptionella ekonomiska tillväxten under perioden - en förutsättning för den politiska argumentationen. Inte minst tog sig detta uttryck, som Ulf Sandström har påpekat i en studie om styrning av forskning, i att partiet skrev fram utmaningarna som för omfattande för enskilda aktörer att möta. Områden där detta framstod som särskilt uppenbart var forsknings- respektive utbildningsfrågor. Socialdemokratin närmade sig under 1950-talet dessa spörsmål med samma optimism som den kraftsamlade för att möta socialpolitikens utmaningar. ${ }^{68}$

\section{En svensk behovsbild formas}

Ragnar Edenmans tal om science policy vid Wenner-Gren Center visade att svenska politiker var receptiva för vad som pågick på den stora scenen vid samma tid. Förutom ecklesiastikministern framträdde också universitetskansler Bengt Petri som tidigare deltagit i mötet med OECD. 
Han berörde i sitt inledningsanförande de storpolitiska konturerna och spelet mellan Europa, USA och Sovjetunionen. ${ }^{69}$ Referenserna till de större aktörerna och det uppenbara inflödet av påverkan utifrån innebar dock inte att den nationella utformningen av en rekryteringspolitik skall ses som produkten av ett passivt mottagande. På Stokes fråga i Paris om positiv propaganda hade svenskarna svarat att en annan lösning redan var påbörjad. Ett omstrukturerat, modernt skolsystem skulle i sig självt klara av att leda eleverna till de mest önskvärda utbildningarna. Det korta svaret rymde mycket av hur svensk utbildningspolitik förhöll sig till det internationella läget. Man erkände grundläggande problembilder och importerade vissa koncept som tillkommit utanför den nationella kontexten. Samtidigt fanns det en tillit till egna lösningar som utgick från inhemska traditioner och självbilder.

Detta reformpolitiska självförtroende kom bland annat till uttryck i en enorm genomgång av det nationella utbildningsväsendet under 1950-talet. Sverige befann sig vid denna tidpunkt i en förändringsperiod som saknar motstycke mätt i antal volymer och kommittéer. På mindre än ett decennium hade 1955 års universitetsutredning, 1957 års skolberedning och 1960 års gymnasieutredning presenterat sina betänkanden på sammanlagt över 7000 sidor.$^{70}$ De många utredningarna var ett resultat av flera samverkande orsaker. De bottnade dels i den socialdemokratiska regeringens strävan att göra skolan mer enhetlig och socialt utjämnande, dels i en vilja att anpassa utbildningssystemets dimensionering efter den kraftigt expanderande mängd elever som förväntades söka sig till högre utbildning. ${ }^{71}$ Tidsperioden hade burit med sig förutsättningar och förhållanden som tidigare inte varit för handen. Den så kallade utbildningsexplosionen innebar att andelen ungdomar som sökte sig till gymnasiet hade fördubblats mellan 1950 och 1960, och prognoserna visade på ytterligare en fördubbling till 1970. ${ }^{72}$ Konsekvenserna av ett felval av utbildning antog allt större proportioner, åtminstone ur samhällets och nationens intresse.

I de många utredningarna gjorde sig den retorik som präglade OECD:s utbildningspolicy gällande. Exempelvis visade interna dokument från Gymnasieutredningen på att det fanns en stark optimism inför det möjliga:

Dels framväxer naturvetenskapen och teknologin såsom levande krafter för att skapa nationell rikedom, vilken vuxit till en förut okänd grad. Dels sjuder de politiska idéer och de sociala krafter, vilka anpassar denna rikedom till sociala ändamål. Dessa förändringar reflekteras i 
Diagram 4. Andelen nybörjare i teoretisk gymnasial utbildning av motsvarande årskull 17-åringar åren 1950—omkring 1985

Bild 2. "Utbildningsexplosionen" visade på de kommande årens utmaningar för svensk skolpolitik. (Bildkälla: SOU 1963:42)

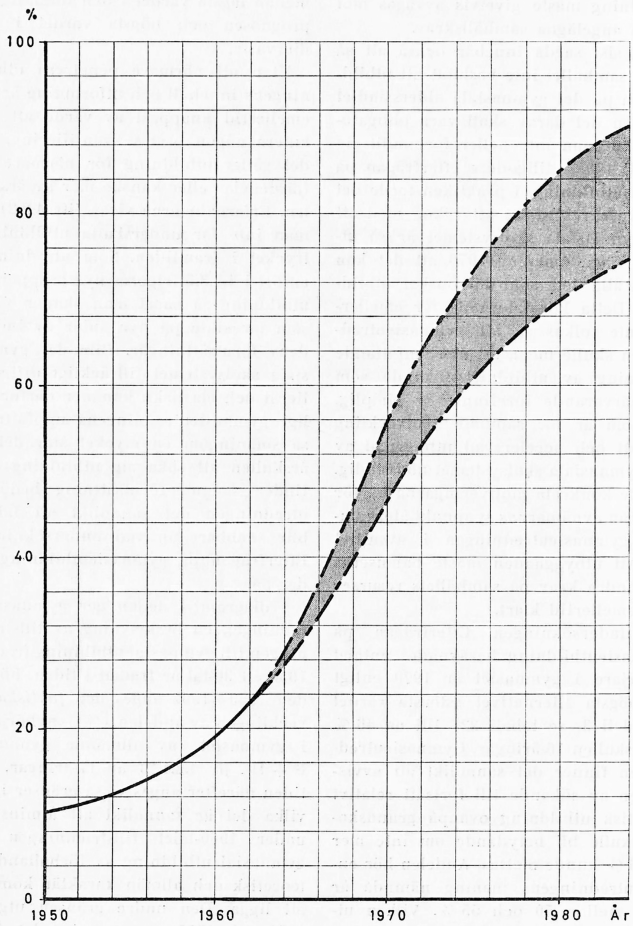

nya tendenser inom ekonomiskt tänkande. En djupare förståelse för de krafter, som påverkar ett långtida ekonomiskt och socialt framåtskridande, leder till erkännande av det faktum att investering i utbildning är en oundgänglig förutsättning för framtida ekonomisk tillväxt. ${ }^{73}$

De utvecklingsoptimistiska tankegångarna var ett referat från en OECD-konferens i Washington 1961 om ekonomisk tillväxt och utbildning som investering. En av huvuddeltagarna hade varit den svenske nationalekonomen Ingvar Svennilson, som vid flera tillfällen under perioden framträdde på den internationella arenan och diskuterade frågan. ${ }^{74}$ Svenska akademiker och politiker spelade överlag aktiva roller för samtidens ekonomisering av utbildningen. Tidigare under året hade en OECD-konferens anordnats i Kungälv med medverkan av pedagogikprofessor Torsten Husén och ecklesiastikminister Ragnar Edenman. ${ }^{75}$ 
Ovanstående arrangemang var ett av många uttryck för att svensk utbildningspolitik under dessa år i stigande utsträckning kom att omsätta vetenskapligt rotade föreställningar om relationen mellan utbildning och ekonomi. Gymnasieutredningen skrev 1963 i sitt huvudbetänkande: "Ekonomiska betraktelsesätt har börjat anläggas, när det gäller att bedöma den pedagogiska verksamhetens 'produktivitet'. Lärarutbildning, byggenskap, hjälpmedel och undervisningsmetoder börjar granskas ur samma synvinklar som de olika produktionsfaktorerna i näringslivet."76 Längre fram i texten konstaterade de sakkunniga: "Huvudproblemen blir [...] hur tillgångarna skall disponeras, d.v.s. hur de olika utbildningsvägarna skall utformas och avvägas mot varandra för att ge optimal utdelning." ${ }^{77}$

Rekommendationen för en sådan avvägning hade pekats ut i Country Reviews: Sweden ett år tidigare. Den slutsatsen var dock inte något som behövde inympas i svensk utbildningspolitik utifrån. I en utredning gjord ett par år tidigare av Sveriges industriförbunds teknikerkommitté hade prognoser för det totala ingenjörsbehovet i Sverige för första gången presenterats. Redan då påtalades risken för ett underskott: "Aktiva åtgärder fordras [...] från såväl myndigheternas som näringslivets sida för att höja utbildningskapaciteten i erforderlig grad."78 Den förstärkta behovsbilden under 1950-talet var framförallt resultatet av en kraftig expansion inom de ingenjörskrävande varvs- och gruvindustrierna, men också inom försvaret som svällde under kalla krigets skugga. ${ }^{79} \mathrm{I}$ rapporten från industriförbundets teknikerkommitté hade en ny typ av beräkningar presenterats som pekade på det intima sambandet mellan produktiviteten i ett samhälle och ingenjörstätheten (antalet ingenjörer per arbetstagare). Under åren 1935-1955 menade kommittén att det gick att identifiera ett linjärt samband i frågan, varför den hade utgått från det även i beräkningar av prognoserna fram till $1975 .{ }^{80}$

Det offentliga utredningsväsendet visade ett stort intresse för industriförbundets ingenjörsprognoser och inkorporerade dem i sina texter. ${ }^{81}$ Här fanns således motsvarigheter till de beräkningar som vägledde arbetet för OECD:s mätningar liksom för det amerikanska Scientific Manpower Program. Det sammantagna budskapet var omöjligt att missförstå. Det skulle i framtiden behövas många fler individer med naturvetenskaplig och teknisk utbildning för att möta arbetsmarknadens behov. Nuvarande utbildningssystem var inte anpassat för att klara av den uppgiften.

I Gymnasieutredningens betänkande bekräftades återigen ett stort 
behov av ingenjörer. Efterfrågan fanns inom alla existerande kategorier institutsingenjör, läroverksingenjör och civilingenjör. ${ }^{82}$ De sakkunniga fann det även motiverat att slå fast det stora behovet av naturvetare i framtiden:

Gymnasieutredningen finner det osannolikt att en även mycket stor examination kommer att ge upphov till ett överskott av naturvetare på arbetsmarknaden. Det är här fråga om en grupp av akademiker som i framtiden ännu mer än nu torde få en vidsträckt användning. Behovet av naturvetenskapligt utbildade vid universitet, högskolor och forskningsinstitut kommer med stor sannolikhet att växa utomordentligt starkt. ${ }^{83}$

Utredningen drog slutsatsen att mer än hälften av landets gymnasieelever borde läsa naturvetenskap eller teknik 1970. I absoluta tal skulle detta innebära en kraftig ökning av antalet examina. ${ }^{84}$

Att utöva styre, skriver Nikolas Rose, är att handla under en särskild problembeskrivning. ${ }^{85}$ Ovanstående utredningar var formativa för den bild av läget som tecknades i den nationella vetenskaps- och utbildningspolitiken under 1950- och 1960-talen och som var knuten till rekrytering av naturvetare och ingenjörer. Med tanke på att flera av utredningarna var parlamentariskt tillsatta och inkluderade representanter för den politiska oppositionen kan flera av de sammanhang där problembeskrivningen ägde rum förstås som partipolitiskt överskridande. Slutsatserna och rekommendationerna bidrog därför till att på många sätt forma en svensk, snarare än enskilt socialdemokratisk, lösning på samtidens utmaningar. ${ }^{86}$

\section{Tidiga rekryteringspraktiker bortom staten}

Vid sidan av den offentliga scenen och bortanför den statliga utbildningsplaneringen hade också enskilda aktörer artikulerat bristen på ingenjörer och naturvetare under tidig efterkrigstid. På så sätt utövades redan en form av positiv propaganda, om än i liten skala. Studier av styrningsmentaliteter har sett det som en begränsning i perspektivet att endast uppmärksamma statens roll, vilket i det här fallet skulle innebära utbildningspolitiken i strikt mening. Istället har man framhållit behovet av att identifiera andra aktörer än exempelvis ministrar, ledande tjänstemän och statsanställda. Det är en viktig anmärkning, eftersom utövandet av makt enligt detta synsätt 
inte är någonting som kan begränsas till en stat. Jag ansluter mig till detta perspektiv och ser styrets utövning som ett resultat av relationerna mellan flera olika auktoriteter. För att förstå framväxten av en allt större mångfald av åtgärder krävs att man även ser till utövandet av positiv maktutövning bortom staten. Då blir det också möjligt att studera de "skiftande allianser" som uppstår mellan samhälleliga auktoriteter i olika projekt för att påverka och organisera individers handlande. Sådana auktoriteter kan identifieras inom exempelvis näringslivet, intresseorganisationer, det civila samhället och andra sammanhang där det finns en strävan att påverka beteenden och aktioner i en specifik riktning. ${ }^{87}$

Jag vill betrakta den successivt växande anslutningen till rekryteringsfrågan som en indikation på problembildens ökande diskursiva räckvidd. Samtidigt är det nödvändigt att i historiskt grundade undersökningar också peka på de skillnader som finns mellan hur olika aktörer beskriver ett problem och vilka resurser de kan ägna åt att försöka lösa det. En aktör som i mitten av 1950-talet kan sägas ha utformat ett tidigt initiativ var Svenska kemistsamfundet. I arrangerandet av de så kallade Berzeliusdagarna tillsammans med den kemiska industrin och Tekniska museet fanns en förhoppning om "att intressera de duktigaste naturvetarna bland gymnasisterna för fortsatta kemistudier". ${ }^{88}$ Arrangemanget syftade till att samla ett hundratal individer för ett par dagars konferenser med inspirerande föreläsningar och gruppdiskussioner. Evenemanget gick av stapeln första gången 1956 då sistaårselever vid läroverkens högsta årskurser i Stockholmsområdet bjöds in till Tekniska museet för att lyssna till ett brett spektrum av föreläsningar. Bland annat kunde de åhöra ett framförande av den nyblivne nobelpristagaren i fysiologi och medicin, professor Hugo Theorell. Dessutom fick publiken bevittna "fantasieggande experiment" förevisade av laborator Torsten Wilner i museets atomarium. ${ }^{89}$

En annan typ av riktad verksamhet har sociologen Boel Berner uppmärksammat i en studie av 1940,- 1950- och 1960-talens ökade efterfrågan på tekniskt kunnig arbetskraft. I tidskriftsannonser från korrespondensinstitut som Hermods och NKI-skolan har hon identifierat olika former av rekryteringsbudskap. I en tid när utbildningssystemet fortfarande dominerades av parallella institutioner fanns det tre vägar till ingenjörstiteln: högskolor (civilingenjör), tekniska läroverk (läroverksingenjör) och korrespondensinstitut eller aftonskolor (institutsingenjör)..$^{90}$

I tidskriftsannonserna riktades ett budskap om ingenjörsyrkets 


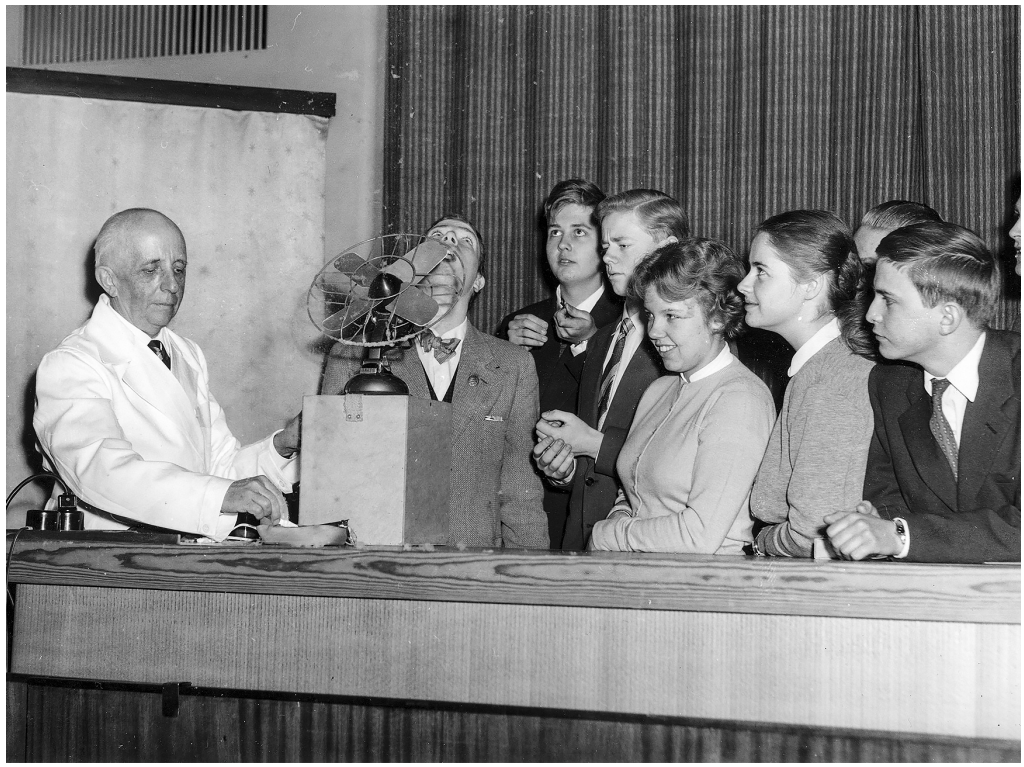

Bild 3. Svenska kemistsamfundets Berzeliusdagar på Tekniska museet 1956. Laborator Torsten Wilner. (Foto: okänd/Pressens Bild/Tekniska museet)

förtjänster till personer med bakgrund i framförallt folkskolans lärogångar vilka saknade möjlighet att nå de högre tekniska utbildningarna. Tilltalet gjorde bruk av berättelsen om flit, ambition och "den långa vägen" till ingenjörstiteln via praktik och kvällsstudier. Ingenjörsrollen rymde dock inte bara drömmen om individens resa från enklare förhållanden. Formuleringen "den långa vägen" kunde också uttrycka en samhällelig ambition. För arbetarrörelsen fyllde ingenjörer från i första hand aftonskolor och institut en speciell funktion då berättelsen om klassresan var parallell med den om folkhemmets och nationens modernisering. ${ }^{91}$

Annonsernas format gav inte plats för några uttömmande motiveringar för att välja ingenjörsyrket. Men i andra sammanhang kunde det rekryterande tilltalet kompletteras med en mer omfattande argumentation. I tekniska tidskrifter som Teknik för Alla togs problemet med teknikerbristen ibland upp i ledarspalterna. På dessa sidor gavs redaktörerna möjlighet att något mer utförligt behandla det växande behovet av ingenjörer. Idéhistorikern Michael Godhe visar i sin studie av sådana texter att motiven för att intressera fler ungdomar för ingenjörsrollen rymde både möjligheten att 
Du som arbetar inom industrin
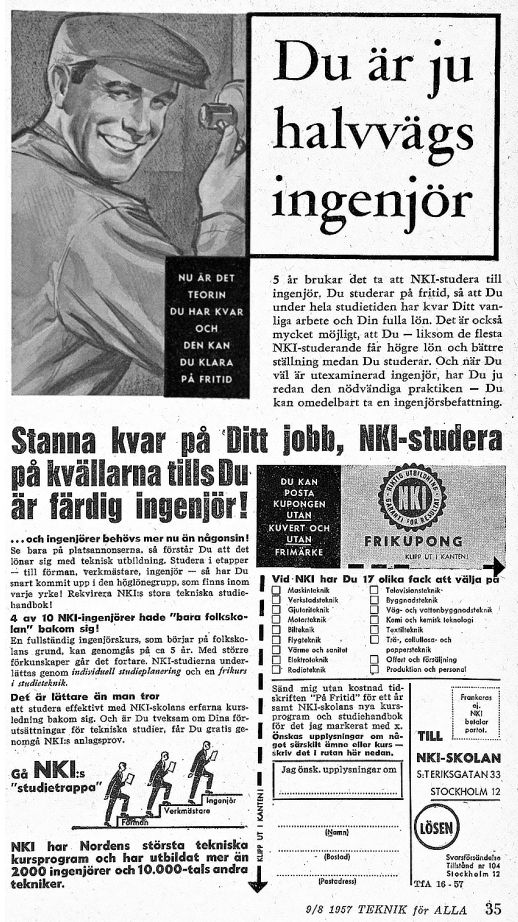

Bild 4. Det ingenjörsrekryterande tilltalet i annonserna från skilda korrespondensinstitut riktade sig ofta till verkstadsarbetare med uppmaningen att "gå vidare". (Bildkälla: Teknik för Alla, nr 16, 1957)

skapa ett idealsamhälle med den moderna teknikens hjälp, och att svensk ingenjörstradition och teknisk utveckling kunde ges en fredsbevarande roll i storpolitikens skugga. ${ }^{92}$

\section{Ord, siffror och byggnader}

Ovanstående kampanjer var exempel på sådan positiv propaganda som senare skulle efterfrågas av Harold Stoke men vänligt avvisas av 1960-talets svenska utbildningspolitiker. Dessa enskilda initiativ saknade emellertid komponenter som var helt nödvändiga för tillväxten av en mer övergripande och vittomfattande problembeskrivning - komponenter som de statliga utredningar som påbörjades under samma tid kunde tillföra. 
För det första hade de enskilda insatserna ofta begränsad räckvidd och berörde främst den egna verksamheten. Korrespondensinstitutens annonser kunde visserligen hänvisa till ett nationellt behov, men var samtidigt inriktade på det egna institutet eller det företag som skulle anställa ingenjören. Inför arrangemanget av Berzeliusdagarna ställdes kvantitet mot kvalitet och mynnade ut i motiv som verkade i en begränsande riktning. Man ville "få så bra kemister som möjligt, inte så många som möjligt". ${ }^{33}$ För det andra kunde den statliga utredningsapparaten genom sina textmängder och omfattande resurser generera kunskap om ungdomar och deras relationer till naturvetenskapliga och tekniska utbildningar på ett sätt som andra aktörer inte förmådde. Där mångfaldigades och vidareutvecklades information på en mycket mer sofistikerad nivå än på exempelvis ledarsidorna i Teknik för Alla.

Annorlunda uttryckt skapade ett systematiskt insamlande och bearbetande av uppgifter om begåvning, prestation och attityder helt andra förutsättningar för liberalt styre genom att det i stor skala omkategoriserade elever i nya kollektivt administrerbara grupper. ${ }^{94}$ Ett tidigt exempel på relationen mellan ett ackumulerat vetande och framskrivandet av nya administrerbara objekt var försöken att identifiera en teknisk-matematisk begåvningsreserv. Arbetet utfördes som en specialundersökning inom 1955 års universitetsutredning. I direktiven hade Ragnar Edenman pekat på den oroande utvecklingen att behovet av civilingenjörer inte täcktes av fler studentexamina från reallinjen. Tvärtom hade andelen realgymnasister minskat i procentuellt avseende sedan mitten av 1940-talet. ${ }^{95}$ Utvecklingen gav vid handen att det kanske var nödvändigt att vidga bilden av vem som kunde bli civilingenjör om man skulle klara av att öka antalet studerande vid de tekniska utbildningarna. Vilka kvalifikationer krävdes egentligen för yrket?

Edenman gav därför Kjell Härnqvist, docent i pedagogik, uppdraget att genomföra en särskild utredning i ämnet. Undersökningen utgick ifrån en fråga om intelligens. Fanns det begåvningsmässiga hinder för utbildandet av fler potentiella civilingenjörer? Härnqvist besvarade frågan nekande. Istället identifierade han en reserv för både reallinjen och efterföljande högre tekniska studier. Han såg inte några hinder för en fördubbling av den dåvarande andelen (2-3 procent av en manlig årskull) som bedömdes klara reallinjen med sådana betyg att de var kvalificerade för högre teknisk-matematisk utbildning. Bland flickorna räknade man med en betydligt större ökning. ${ }^{96}$ 
Resonemanget om begåvning hade varit synonymt med frågan om kvalitet. Men Härnqvists studie hade på vetenskaplig väg öppnat upp för en betryggande slutsats. Risken för bristande kvalitet hos framtida ingenjörer framstod som låg vid ett ökat intag av studerande. Länge hade begåvningsresonemang hindrat tillväxten av individer inom högre utbildning, inte minst personer från de mindre bemedlade klasserna. Den borgerliga meritokrati som präglade läroverksvärlden fungerade under lång tid enligt en självförstärkande logik. Idéerna om att fallenhet för högre studier var en bristvara gav stöd för att endast en liten andel barn läste vid läroverket. Dominansen vid dessa institutioner av unga från den övre medelklassen stärkte tron på nedärvd begåvning och etablerade ett empiriskt underlag för ett bevarande av den rådande ordningen. Dessa individers fortsatta framgångar inom utbildningsvärlden kunde i sin tur bekräfta idéernas riktighet. ${ }^{97}$

Vid de tekniska läroverken var den sociala sammansättningen något annorlunda än vid de allmänna, vilket gjorde titeln läroverksingenjör till en återkommande sinnebild för klassresan och duglighetens triumf. Men även dessa utbildningar expanderade relativt långsamt under 1900-talets första hälft, liksom de högre tekniska utbildningarna vid Kungliga Tekniska högskolan i Stockholm och Chalmers tekniska institut i Göteborg. ${ }^{98}$

I de många utredningar som genomfördes från 1800-talets mitt och framåt saknades inte förespråkare för utbyggnad av teknisk undervisning på olika nivåer. Ofta framfördes krav på fler ingenjörer mot bakgrund av innovationer och behovet av tillämpningar av ny teknik. ${ }^{99}$ Även gällande den lägre tekniska undervisningen ventilerades vid återkommande tillfällen önskemål om expansion. Den sistnämnda byggdes ut i omgångar och gick sedan upp i det svenska yrkesskolsystemet 1918. ${ }^{100}$

Oviljan att bygga ut den högre utbildningen i Sverige var dock av tradition stark. Skälen var flera. Ett argument som länge cirkulerat var rädslan för att skapa ett högutbildat proletariat. Farhågorna bottnade i en flera hundra år gammal diskussion om risken med akademikeröverskott. Såväl Anders Berch, professor i ekonomi vid Uppsala universitet i mitten av 1700-talet, som ledamöterna av 1820-talets Snillekommitté Hans Järta och Erik Gustaf Geijer uttalade oro inför en sådan utveckling. Den senare menade att en överproduktion av studenter riskerade att rycka sönder organisationen vid universiteten och förvandla dem till splittrade nyttoenheter, fjärran från sin uppgift att förmedla kunskap för kunskapens egen skull. Ett annat argument var risken för halvbildning och skapandet 
av individer med lärda fördomar - en kombination av ytlig kunskap och överdriven självuppfattning. ${ }^{101}$

I sin studie av svensk utbildningsplanering under 1900-talet skriver Mac Murray att dessa argument allt som oftast gällde klassiskt-humanistiska kunskaper, snarare än naturvetenskapliga och tekniska studier som på ett annat sätt betraktades som nyttiga. ${ }^{102}$ Men debatter under 1800-talets andra hälft och 1900-talets början visade också på farhågor gällande ökad intagning till högre teknisk utbildning och frambringandet av ett ingenjörsproletariat. ${ }^{103}$ Överingenjören vid AB Separator, Erik August Forsberg, uttalade sig i Svensk Tidskrift om skälen för och emot en utvidgning av Tekniska högskolans verksamhet. Det fanns en risk, menade han, att många nyutbildade ingenjörer skulle söka sig utomlands om trängsel uppstod på den inhemska marknaden.

Vidare förefinnes faran af ett ingenjörsproletariat. Ett sådant är aldrig önskvärdt, dels emedan en förlust uppstår på grund af ej till användning kommen dyrbar utbildning, dels, och framför allt, emedan en klass af missnöjda individer uppstår, hvilken af lätt insedda skäl bidrager att rekrytera de samhällsupplösande elementen. ${ }^{104}$

Under 1930-talet fortsatte debatten om farorna med utbyggnad av den högre utbildningen. En av de mer måleriska skildringarna gav lektor Sven Ohlon i Göteborgs Handels- och Sjöfarts-Tidning 1932:

Det var biltoga akademici och alls icke det industriella proletariatet, som gjorde bolsjevikrevolutionen i Ryssland, det är arbetslösa akademici, som bära upp hitlerismen i Tyskland, och det är i ej ringa mån sysslolösa studenter, som sätta fart på Lapporörelsen i Finland. Må vi inför dessa avskräckande exempel i tid betänka, vad vår frid tillhörer! ${ }^{105}$

Även om Ohlons skräckscenario främst gällde de fria fakulteterna stod inte ingenjörsutbildningarna helt utanför diskussionen: "Såväl till tekniska högskolan och Chalmers som till handelshögskolorna har tillströmningen ökat katastrofalt under den sista femårsperioden." 106

I en av de stora utredningarna under mellankrigstiden behandlades "tillströmningen till de intellektuella yrkena" och det framtida behovet av examinerade från gymnasier, universitet och högskolor. De sakkunniga kunde bekräfta att rädslan för ett akademikeröverskott var fortsatt stor 
och att det inte gick att uppbringa någon säker uppgift om efterfrågan på högre utbildad teknisk arbetskraft. Men de ansåg sig dock ha tillräckligt med information för att kunna konstatera att "det ur många synpunkter skulle vara till fördel med en utökad produktion av högskoleutbildade ingenjörer". ${ }^{107}$

Trots sådana uttalanden blev resultatet magert i termer av expansion för de tekniska högskolorna. Den stora utbyggnaden kom istället efter 1950 när rädslan för överproduktion fallit ifrån i debatten. ${ }^{108}$ Med Kjell Härnqvists specialstudie om teknisk-matematiska reserver hade även argumentet om begåvning spelat ut sin roll. Som ett resultat kom talet om en utbyggnad av teknisk utbildning i Sverige i ett annat läge.

Härnqvists utredning är ett exempel på hur den svenska statistik som allteftersom mångfaldigades i rekryteringsfrågan fungerade på samma sätt som OECD:s verksamhet. Prognoserna skapade illustrativa glapp mellan olika jämförelsepunkter och etablerade på så sätt diskursiva utrymmen för handlande i ett senare skede. Historiska studier av statistik har visat på dess aktiva och skapande roll. Prognoser beställs alltid i ett specifikt sammanhang, men bör för den skull inte endast ses som en avspegling av sin kontext. Politiserandet av siffrorna - vad som skall mätas, hur det skall ske och hur ofta - sker således samtidigt som siffrorna påverkar den fortsatta politiken. ${ }^{109}$

Som en följd av utbildningsstatistiken fogades naturvetenskap och teknik samman till ett mer förtätat problemområde. Men det var inte bara de nya siffrorna som skapade förutsättningar för denna tillväxt av rekryteringspolitiken under 1950- och 1960-talen. Bristtematiken etablerades även på språklig väg. Talet om underskott på naturvetare och tekniker var inte ett passivt utförande av ett utredningsuppdrag. Istället var det en diskurs som efter hand formade ett förhållningssätt inom vilket en specifik form av styre blev möjlig. Framställningen i den nya utbildningsplaneringens texter återgav således inte bara ett rekryteringsproblem - den producerade det och tillhandahöll samtidigt det handlingsutrymme inom vilket organiserandet av individers handlande skulle komma att bli möjligt.

Ett tydligt exempel på det ovanstående är att naturvetenskap och teknik nu började adresseras, förstås och talas om på samma sätt. Härigenom möjliggjorde utredningstexterna att man mer aktivt sammanfogade utbildningar i dessa ämnen, ofta genom tydligare avgränsningar mot andra discipliner. Edenman valde i direktiven till Gymnasieutredningen att tala 
om olika begåvningstyper och särskilde "den tekniskt-naturvetenskapliga" från exempelvis den språkliga. ${ }^{110}$ Denna tanke ansågs också bottna i vad eleverna själva hade sagt i olika undersökningar. Utredningen menade därför att det vore "för åtskilliga elever en stor fördel, om i framtiden mer än nu naturvetenskaplig och teknisk gymnasieutbildning kunde betraktas som variationer på samma tema". ${ }^{11}$

Talet om naturvetenskap och teknik som ett tema eller en begåvningstyp visade att man såg ett alltmer intimt samband mellan de båda verksamheterna. Detta var inte isolerat till utredningsväsendet. Vid konferensen Vetenskapen i framtidens samhälle på Wenner-Gren Center 1963 kretsade många av de forskningspolitiska anförandena kring fysikens, kemins och biologins nära koppling till industrin. Statsminister Erlanders nära vän Torsten Gustafson uppehöll sig bland annat vid atomenergins omsättning i kärnkraft och ultraljudets tekniska tillämpningar i ekolodning, medan Arne Tiselius talade om den nya biologins konsekvenser inom medicinen. I den efterföljande diskussionen menade professorn $\mathrm{i}$ fysik Kai Siegbahn att den "tekniska och den naturvetenskapliga forskningen kan numera ej skiljas från varandra". ${ }^{112}$ Vetenskapshistorikern Hans Weinberger har pekat på att denna uppfattning om vetenskap och teknik blev alltmer utbredd bland en rad aktörer i Tekniksverige - forskningsråd, tidskrifter, myndigheter och ingenjörsorganisationer. Skiljelinjerna mellan universitet och industri, teknik och vetenskap samt forskning och utveckling tonades ned, vilket erbjöd förutsättningar för institutionella samgåenden. ${ }^{113}$

Tanken på det nära sambandet tog sig även materiella uttryck. I ett förarbete till Gymnasieutredningen hade den så kallade "P-gruppen" (Prognos- och planeringsgruppen) skrivit: "Den påbörjade utvecklingen på nu existerande högskoleorter mot en gradvis integration av matematisk-naturvetenskaplig och teknisk utbildning och forskning synes, inte minst av arbetsmarknadsskäl, böra påskyndas."114 Det som avsågs var bland annat byggandet av lokaler för Lunds tekniska högskola, vilket markerade ett institutionaliserande av naturvetenskap och teknik som någonting djupt integrerat. I rapporter till $\mathrm{OECD}$ berättade svenskarna om de nya byggnaderna som planerats utifrån ambitionen om största möjliga samverkan mellan forskning och undervisning inom den nya högskolan och universitetets naturvetenskapliga fakulteter.

Samma princip gällde för en ny matematisk-naturvetenskaplig fakultet vid Göteborgs universitet: undervisningen inom matematik, teoretisk 
fysik, mekanik, fysik och kemi skulle utformas på ett sätt som inkluderade Chalmers tekniska högskola i större utsträckning. I sin kommentar betraktade OECD det hela som en naturlig konsekvens av det omöjliga i att upprätthålla rågångar mellan verksamheten inom "rena" naturvetenskapliga ämnen och tillämpad teknisk verksamhet vid de tekniska högskolorna. ${ }^{115}$

Att man talade om och räknade på problemet på detta sätt etablerade utgångspunkter som inte uttryckte något särskiljande mellan naturvetenskapliga och tekniska utbildningar. I Country Reviews: Sweden omtalades de båda som stående inför samma problem och i behov av samma lösningar:

During the past two decades there has been a remarkable development in technology and science, and considerable changes in the social and economic structure of nearly every country. Completely new problems have arisen to which a solution must be found. During this period however, the basic curricula of the universities and institutes of technology have remained more or less unchanged. In our opinion there is an urgent need to review the existing curricula and see to what extent they are in harmony with prevailing needs. Where they are not, new schemes and proposals should be made; the existing traditional organization of the university units (faculties, institutes of technology), and their curricula, should not be allowed to constitute a handicap to change. ${ }^{116}$

Här ser vi ytterligare en skillnad mellan den problembild som skrevs fram av staten och de kampanjer som bedrevs av enskilda aktörer som NKI, Hermods och Kemistsamfundet. Medan korrespondensinstituten projekterade ingenjörer, letade de senare efter dugliga kemister. Inom Hermods eller Berzeliusdagarnas problemhorisont rymdes inte det mer integrerade sättet att tänka, tala och räkna på en bredare problembild. Snarare tvärtom. Berzeliusdagarna drevs av tanken på konkurrens med andra områden. ${ }^{117}$

Successivt skulle därmed 1950-talets "teknikerbrist" ge plats åt en bredare beskrivning av underskottet på ingenjörer och naturvetare. Den betydelse som de båda yrkesgrupperna ansågs ha för forskning, ekonomisk utveckling och industriell produktionsökning, gjorde den sammanlagda behovsbilden större än summan av sina delar. En situation 
där utbildningssystemet inte mötte arbetsmarknadens behov riskerade att hindra den inneboende potentialen i det kluster av förhoppningar som skapats i samtiden.

\section{Det nya utbildningssystemets visualitet}

Det var också antagandet om ett tätare samband mellan naturvetenskap och teknik som det nya gymnasiets struktur skulle förmedla. Gymnasieutredningen föreslog i sitt betänkande att slå samman de tre tidigare läroverksformerna allmän, teknisk och ekonomisk till en enda. På så sätt skulle man kunna rubba den rådande uppfattningen om vilka lärokurser som låg närmast varandra. Här följde man Edenmans direktiv och önskemål:

Det visar sig [...] att de traditionella föreställningarna om gymnasiets uppdelning på en allmän, en ekonomisk och en teknisk sektor i själva verket är i vissa avseenden mindre naturlig än en gruppering $i$ humanistisk-språklig [...] en ekonomiskt-samhällsvetenskaplig [...] och en naturvetenskaplig-teknisk sektor. ${ }^{118}$

Nyordningen bekräftade de forsknings- och vetenskapsideologiska utgångspunkter som uttryckts på Wenner-Gren Center tidigare samma år. Rent schematiskt illustrerade strukturen hur skolan som institution anpassats på ett sätt som åtföljde talet om en "naturlig" uppdelning (se bild 5). Den visualitet som det nya utbildningssystemet förmedlade skulle därmed komma att ge ökade förutsättningar för att förstå och tala om naturvetenskap och teknik på ett mer sammanflätat sätt, samtidigt som det markerade en tydligare gräns mot andra discipliner. Detta gav strukturen en aktiv roll som går att förstå i flera led. Förutom att den var avsedd att kommunicera med skolungdomar på väg mot gymnasiet kan den också betraktas som delaktig i själva artikulerandet av rekryteringsproblemet vilket härmed byggdes in i gymnasiets organisation.

I och med den nya ordningen skulle man också komma att bryta med en i Sverige djupt rotad läroverkstradition. I utbildningshistoriskt avseende var tekniska och naturvetenskapliga studier ännu vid 1950-talets slut två skilda verksamheter inom skolväsendet. Om tekniska utbildningar i Sverige kan generellt sägas att deras status var i stigande under 1900-talets första hälft, men att de ändå befann sig på en låg nivå jämfört med många 


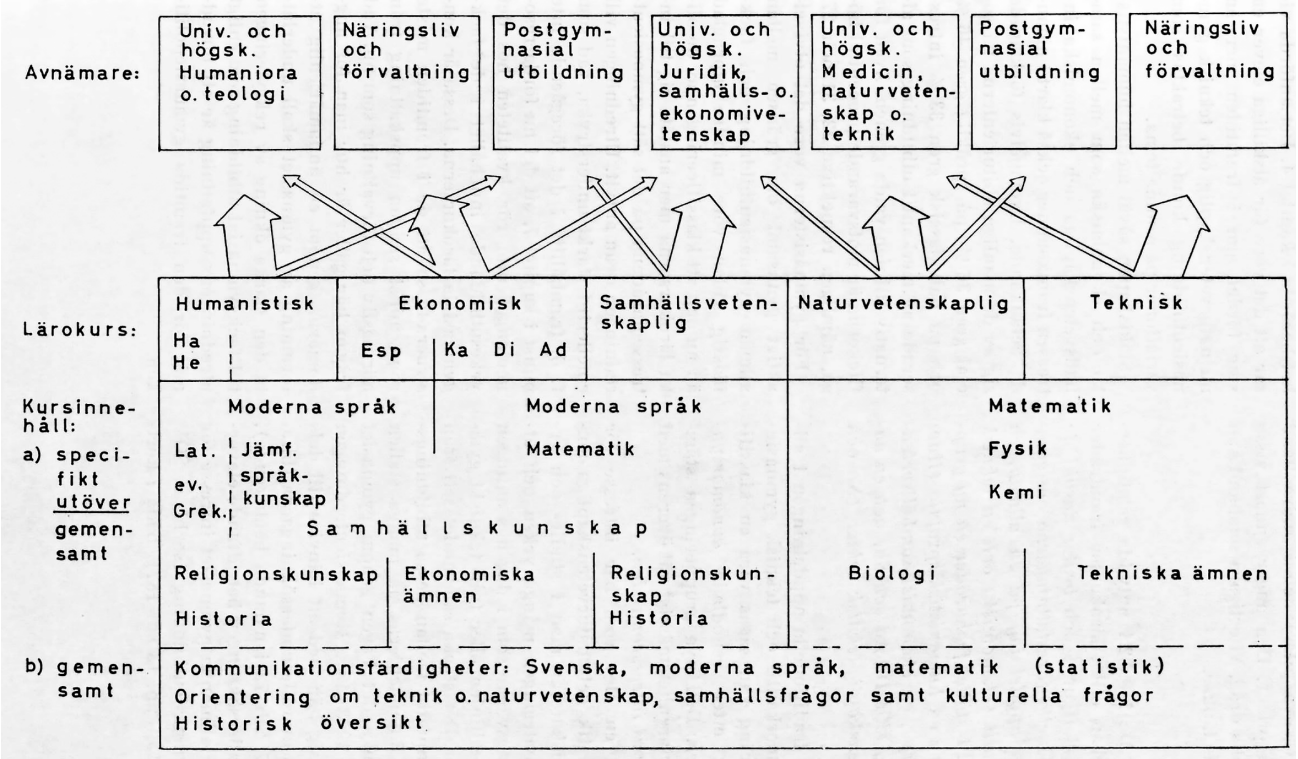

De huvudsakliga relationerna mellan gymnasieutbildningens innehåll och gymnasiets olika avnämare

Bild 5. Det nya gymnasiet bröt med en hundraårig läroverkstradition och placerade på ett tydligt sätt naturvetenskaplig och teknisk utbildning bredvid varandra. (Bildkälla: SOU 1963:42)

andra traditionstyngda discipliner. Inom såväl folkskolan som de allmänna läroverken saknade tekniken ett eget ämne i läroplanerna. Istället var vad man kan beteckna som ett tekniskt innehåll insprängt i ett flertal andra ämnen - i folkskolan exempelvis inom slöjd, naturkunnighet och hembygdskunskap. ${ }^{119}$

I andra delar av skolsystemet fanns exempelvis tekniska elementarskolor som efter 1918 skulle kallas tekniska läroverk. I läroplanen för dessa utbildningar fanns olika former av tekniska ämnen. För dessa institutioner - och för teknisk utbildning överlag - var det av stor betydelse när det 1901 bestämdes att genomgången utbildning innebar behörighet till teknisk högskola. ${ }^{120}$ Samtidigt som detta var en uppvärdering av skolformen kom den dock att kvarstå i läroverksvärldens periferi då en examen inte kvalificerade för inträde vid universiteten; så sent som 1960 utbildade de tekniska läroverken endast 20 procent av den svenska gymnasieungdomen medan majoriteten istället gick vid de universitetsförberedande allmänna läroverken. ${ }^{121}$ 
Det var bland annat denna snedfördelning och marginalisering av de tekniska utbildningarna som Gymnasieutredningens förslag var tänkt att motverka. För att nå en större representation av barn från andra socialgrupper var det viktigt att eleverna blev mindre fördomsfulla i sin värdering av de tidigare fackgymnasiernas innehåll. Att den tekniska linjen nu skulle berättiga till studier vid universitet förtydligade detta försök att likställa teknisk undervisning med annan. ${ }^{122}$ För dem som önskade läsa vidare vid universitet och högskola gällde treårig teknisk gymnasielinje, medan de som skulle bli gymnasieingenjörer gick ytterligare en årskurs, med kraftig dominans av tekniska ämnen. Denna fyraåriga tekniska linje bedömdes kunna ersätta den tidigare utbildning som gett titeln läroverksingenjör. ${ }^{123}$

I kontrast till detta åtnjöt naturvetenskaperna hög prestige i skolvärlden. I kraft av en lång tradition som enskilda ämnen förvaltade de ett arv som bottnade i den akademiska världens status. Från sitt inrättande 1856 hade läroverkets reallinje successivt flyttat fram positionerna för den naturvetenskapliga ämnesgruppen inom den av tradition humanistiskt dominerade skolformen. Under lång tid ansågs reallinjen dock med sin naturvetenskapliga tyngdpunkt inte som bäst förberedande för universitetsstudier. Fram till 1891 ledde den endast fram till "lilla studentexamen" och dess elever var tvungna att komplettera med latin för att kunna börja vid något av rikets universitet. Under efterkrigstiden skulle den dock passera latinlinjen som en kungsled till högre studier eftersom den gav bredast behörighet till högskolan. ${ }^{124}$

Även i sociologiskt avseende måste skillnaderna mellan naturvetenskaplig och teknisk utbildning beskrivas som betydande. Reallinjen hade under första halvan av 1900-talet etablerat sig som en elitlinje. Där gick elever som med sociologen Pierre Bourdieus terminologi besatt ett betydande kulturellt kapital. Vid 1960-talets början kom de i högre grad än elever på övriga linjer från en bakgrund i akademiker- och högre tjänstemannahem. ${ }^{125}$ Denna karaktär skulle prägla inriktningen även fortsättningsvis under efterkrigstiden. Dessutom förstärktes den av en meritokratisk aspekt då linjen successivt drog till sig elever som $\mathrm{i}$ betygsmässigt hänseende intog en särställning. ${ }^{126}$

Vid de tekniska läroverken gick, med samma terminologi, kapitalsvagare elever. 1960 års gymnasieutredning visade att de i högre utsträckning än elever vid de allmänna läroverken kom från arbetar-, jordbrukar- och hantverkarhem. Rekryteringen till teknik som ämne, utbildning och yrke 
var således annorlunda än den till naturvetenskapen, någonting som de stiliserade arbetarporträtten i annonserna från korrespondensinstituten också vittnade om. De tekniska läroverkens elever skulle heller inte nå lika starka skolprestationer under efterkrigstiden. ${ }^{127}$ Trots att linjen möjliggjorde en klassresa och höll drömmen om en förbättrad samhällsposition vid liv, var mönstret vad gäller fortsatta studier också tydligt avvikande jämfört med reallinjens studenter. De senare gick efter fullbordad examen vidare till högre utbildning i större utsträckning än de som tagit examen vid tekniska läroverk. ${ }^{128}$

Dessa skilda pedagogiska och sociala traditioner drunknade på många sätt i framväxten av det nya gymnasiet och samtidens behov av att betrakta skolans naturvetenskap och teknik som sammanhållna. Gymnasieutredningen lade fram skäl till varför tydliga rågångar mellan de båda kategorierna inte alltid var en nödvändighet: "Det är också viktigt att observera att naturvetare och tekniker kan [...] beräknas substituera varandra i ökad omfattning." ${ }^{129}$ Något som bidrog till att sudda ut konturerna ytterligare var att de flesta som läste vid de tekniska högskolorna av tradition kom från reallinjen snarare än från de tekniska läroverken. Detta skapade ibland oklarheter inom den administration och statistik som med nödvändighet följde av rekryteringspolitiken. En elev som under gymnasietiden kunde benämnas som naturvetare kunde därför mycket väl klassas som ingenjör inom den högre utbildningen. ${ }^{130}$

Som tidigare nämnts menade de sakkunniga inom Gymnasieutredningen att naturvetenskaplig och teknisk linje tillsammans borde härbärgera mer än hälften av landets gymnasieungdom 1970. Detta skulle innebära en fyrdubbling av antalet examina från teknisk gymnasieutbildning och en ökning inom den naturvetenskapliga lärogången med cirka 30 procent. Den senare skulle då vara den i särklass största gymnasieutbildningen i landet. Som en konsekvens borde den humanistiska utbildningen krympa markant och bli den minsta. ${ }^{131}$

Genom sådana prognoser gjordes gymnasiepolitiken synonym med den högre utbildningens planering. Statsvetaren Bo Lindensjö skriver att samma tankar vägledde universitetens dimensionering. Humanisterna behövde bli färre, dels genom att styras mot mer samhällsnyttiga ämnen som naturvetenskap och teknik, dels genom så kallad avlänkning vilket innebar att söka föra in dem mot annan mer praktiskt inriktad eftergymnasial utbildning. ${ }^{132}$ Resonemanget frilade den befolkningspolitiska aspekt som dimensioneringen av gymnasiet hade. Även om det totala 
antalet gymnasister förväntades öka, var nivåerna som sattes för de nyttiga ämnena beroende av att flera tusen ungdomar förmåddes välja dem istället för onyttiga sådana.

\section{Vetenskapspolitiken och den trolösa ungdomen}

När studenterna vid Stockholms universitet ockuperade sitt eget kårhus på Holländargatan i maj 1968 var det i protest mot den nyligen föreslagna högskolepolitiken. I det redan då famösa förslaget från UKAS (Universitetskanslersämbetets arbetsgrupp för fasta studiegångar) gav de ansvariga uttryck för viljan att strukturera och effektivisera universitetsutbildningen i landet, inte minst med tanke på genomströmningen. Framförallt inom de filosofiska fakulteterna ansågs studierna ta alltför lång tid. Genom inrättandet av så kallade fasta studiegångar skulle studenterna fås att följa en mer formaliserad väg genom den högre utbildningen. Detta innefattade också tröskelresultat för övergång till nya kurser och avvisningsregler för studenter med otillräckliga resultat. ${ }^{133}$

Kårhusockupanterna krävde ett samtal med de ansvariga statsråden Olof Palme och Sven Moberg. Senare på kvällen gjorde Palme ett djärvt framträdande i ett försök att gjuta olja på debattens vågor. Hans möte med studenterna har dock beskrivits som en misslyckad dialog och en symbol för de överlag vidgade klyftorna mellan utbildningspolitiken och de nya ungdomskullar som fann att det socialdemokratiska projektet inte talade till deras generation. Istället för att förslagen uppfattades som en modernisering av den på många sätt feodala universitetsstrukturen klandrades UKAS på en rad olika punkter. Mildare kritiker talade om byråkratisk klåfingrighet, andra om en utlöpare av kapitalistisk konformism. ${ }^{134}$

Protesterna mot UKAS illustrerar en tydlig skillnad för den socialdemokratiskt präglade utbildningspolitiken jämfört med decennierna innan. Då hade förslag på reformer ofta skrivits fram i parlamentariska utredningar med delar av den politiska oppositionens godkännande. $\mathrm{Nu}$ kom kritik inte bara från vänsterstudenter med medelklassbakgrund utan också från flera av de andra partierna, från media och från företrädare för universiteten. ${ }^{135}$ Tidsandan i slutet av 1960-talet, och de konflikter som samtidigt utspelade sig på många håll i omvärlden mellan studenter och regeringar, gjorde det svårare att bemöta utmaningarna inom utbildningsområdet med samma käcka framstegsoptimism som präglat retoriken i exempelvis Framstegens politik från 1956. När Palme en tid 
senare presenterade regeringens proposition i frågan hade UKAS tagit intryck av kritiken och mildrat sitt tidigare förslag. ${ }^{136}$

I skuggan av händelserna i kårhuset uppenbarade sig andra minst lika problematiska förhållanden, såväl för det socialdemokratiska partiet som för den allmänna teknik- och vetenskapsoptimismen. Mestadels i medieskugga men synligt i utbildningsstatistiken hade valen till den nya gymnasieskolan börjat bilda ett oroväckande mönster. Den nyskapade tekniska linjen hade inte attraherat ungdomarna i tillräckligt stor utsträckning. År 1966 var andelen förstahandssökande 20,2 procent och strax under riktvärdena. Året efter utgjorde de bara 14,4 procent. För 1968 hade de rasat under 10 procent. ${ }^{137}$ Liknande siffror uppenbarade sig för fackskolan. Denna tvååriga skolform hade införts som ett slags yrkesinriktad påbyggnadsutbildning på grundskolan och hade en teknisk, en social och en handelsinriktad gren. Målet var från början att drygt en tredjedel skulle läsa den tekniska grenen, men på två år hade dock antalet förstahandssökande sjunkit från knappt 39 till 22 procent. ${ }^{138}$

Naturvetenskaplig linje hade inga problem med att fylla sitt mål på 30 procent vid antagningen. Men många elever valde att hoppa av utbildningen efter ett år och byta till samhällsvetenskaplig linje istället. Denna "överströmning" innebar att procentsatserna halkade ned en bra bit under målet. ${ }^{139}$

I maj 1968 - samtidigt som protesterna mot UKAS rasade som värst - skickade Skolöverstyrelsen en skrivelse till regeringen där den målade upp konsekvenserna av utvecklingen:

Om denna överströmning får fortsätta obehindrat uppstår en fördelning av eleverna på gymnasiets olika studievägar, som helt avviker från de i riksdagsbeslutet 1964 angivna riktpunkterna. Därmed äventyras den utbildningspolitiska målsättningen. [...] Totalt uppstår en betydande diskrepans mellan samhällets och arbetsmarknadens beräknade behov av arbetskraft med olika kvalifikationer å ena sidan och gymnasiets produktion av utbildade på olika studievägar å den andra. ${ }^{140}$

Den torra kansliprosan till trots var det uppenbart att ungdomen knappast vallfärdade till naturvetenskapen och tekniken så som man hoppats. Siffrorna var ett tydligt underkännande av 1960-talets utbildningsplanering och det reformerade system som Sven Moberg, Bengt Petri och Frank Öhman så trosvisst hade lutat sig mot i Paris. För att återvända till 
utbildningssystemets visualitet var det på många sätt just denna som hade tilldelats ett grundskott. Svenskarna hade utgått från idén att förtydliga vilka studiegångar som var de bästa ur arbetsmarknadssynpunkt. Beskeden från det nya gymnasiet gav sämsta tänkbara budskap tillbaka. Just de linjer och discipliner som behövde öka var istället de som minskade mest.

För den socialdemokratiska regering som byggt så mycket av sitt förtroendekapital på vetenskap och utbildning bör siffrorna ha varit svårbegripliga, dels mot bakgrund av den egna samhällsvisionen, dels eftersom undersökningar i början av 1960-talet hade vittnat om att eleverna önskade mer naturvetenskap och mindre humaniora i gymnasiet. ${ }^{141}$ Statistiken ökade spänningen i första hand mellan den planerande, teknikoptimistiska arbetarrörelsen och en ny ungdomsgeneration som den inte begrep sig på. Den sociala ingenjörskonst som präglade folkhemspolitiken framstod som enklare att genomföra när det gällde att reformera stora system, bygga nya skolor och skapa fler utbildningsplatser. När det gällde att forma nya individer för dessa system hade man svårare att leva upp till sina egna högt ställda mål.

I ett bakåtblickande perspektiv kan det sena 1960-talets utbildningsstatistik betraktas som en av flera samhälleliga motbilder mot teknikens löftesbringande nimbus. Sådana bilder har uppstått kontinuerligt under 1900-talet parallellt med vetenskapens framflyttade positioner inom näringsliv, politik och kulturliv. Under första halvan av seklet kom de bland annat till uttryck i debatter om materialistisk världsåskådning, determinism och ett avförandligande av världen. ${ }^{142}$ Efter andra världskriget framfördes bilden av teknikens och vetenskapens janusansikte i relation till atomvapen och miljöförstöring. Ungdomarnas val av utbildning formade ett annat, mer stumt och ansiktslöst avståndstagande från politikernas önskan om ett samhälle med fler tekniker och naturvetare.

I ett försök att råda bot på försämringen initierade Skolöverstyrelsen flera på varandra följande åtgärder. För det första bestämdes det att antalet studerande på teknisk gymnasielinje som lägst skulle motsvara mellan 15 och 20 procent av gymnasieeleverna. På så sätt kunde målen uppnås genom överflyttning, vilket i praktiken innebar att ett stort antal elever som inte valt teknisk linje i första hand ändå blev placerade där. ${ }^{143}$

För det andra föreslog myndigheten att nyare och hårdare former av styrning skulle införas för att hindra "flykten" från naturvetenskap (och teknik) mellan årskurs 1 och 2. Målet var att "den sammanlagda relativa andelen för teknisk och naturvetenskaplig linje ej får nämnvärt understiga 
de relativa andelarna för motsvarande tillvalsgrupper i årskurs 1 närmast föregående läsår". Endast om "särskilda skäl" förelåg skulle man få byta från sådana linjer. ${ }^{144}$

Regeringen sade i 1969 års statsverksproposition dock nej till vad som i praktiken liknade ett förbud mot avhopp från naturvetenskaplig linje. ${ }^{145}$ Frågans förment administrativa karaktär dolde en kollision mellan två bärande visioner för det moderna välfärdssamhällets förverkligande - ett ökat behov av vetenskap och teknik å den ena sidan, och principen om individens fria val av utbildning å den andra. Någon sådan motsättning skrevs inte ut i regeringens ställningstagande. Däremot framgick det att Skolöverstyrelsen hade fört sådana diskussioner. Den folkpartistiske ledamoten Håkan Berg reserverade sig i ett uttalande som fångar den inneboende motsättningen i 1960-talets utbildningspolitik:

Jag delar helt överstyrelsens uppfattning rörande den önskvärda fördelningen av eleverna mellan gymnasiets och fackskolans olika linjer. Även enligt min mening är sålunda de naturvetenskapliga och tekniska linjerna de som allmänt sett ger den bästa utbildningsberedskapen för framtidens arbetsmarknad. Med hänsyn dels till att elevens frihet i valet av studiegång utgjorde en av de bärande principerna för 1964 års gymnasiereform, dels till den information som med utgångspunkt häri givits elever och föräldrar om att inget val på gymnasium och fackskola skall leda till återvändsgränder, anser jag det emellertid vara riktigast att i första hand pröva möjligheten att genom en intensiv information och eventuellt justeringar i läroplanerna söka vända tendenserna till flykt från de naturvetenskapliga och tekniska linjerna, innan man tillgriper metoden med administrativa regleringar. ${ }^{146}$

Regeringens beslut skulle ligga i linje med Bergs tankegångar om bland annat "intensiv information" och åtgärder i skolan. Statsverkspropositionen underströk behovet av att "överväga andra åtgärder för att få till stånd en ändamålsenlig fördelning av de studerande på olika linjer i gymnasiet och därvid söka finna sådana metoder som tar fasta på de faktorer som styr elevernas val". ${ }^{147}$ När frågan senare berördes i statsutskottet samma år betonades att lösningarna skulle vara av "pedagogisk samt studie- och yrkesorienterande natur". ${ }^{48}$

Beslutet innebar således att man behöll målsättningen men ändrade metoderna. Förskjutningen av tillvägagångssätt bildade i retrospektiv 
en ironisk påminnelse om den överdrivna förtröstan på systemet som kommit till uttryck i mötet med OECD. Tron på planeringen gjorde den gången att arbetet med positiv propaganda nedprioriterades. Det nekande svaret vid mötet i Paris hade ett knappt decennium senare förbytts i ett trevande efter just sådana åtgärder.

\section{Valfrihetens samhälle och det liberala styrets rationalitet}

Skolöverstyrelsens idéer om hårdare styrning av elevernas utbildning låg på regeringens bord samtidigt med förslaget från UKAS under det stormiga året 1968. Debatten om det senare utspelade sig tidvis framför tv-kamerorna och på dagspressens ledarsidor, medan de förra behandlades i konselj. För den som hade kännedom om de båda processerna var det dock uppenbart att de hörde samman på mer än ett sätt. UKAS utgjorde genom sin inriktning på högre utbildning ett slags slutstation för den modernisering av utbildningsväsendet som påbörjades under 1950-talet och där dimensioneringen av antalet elever på gymnasiet var en mycket viktig fråga.

De två ärendena förenades också av avvägningen av hur tungt individernas valfrihet skulle få väga. En av de punkter där UKAS-förslaget fick ta emot häftig kritik var de fasta studiegångarna och graden av styrning genom systemet. I båda fallen modifierade regeringen regelverket utan att ändra på de ursprungliga målsättningarna. ${ }^{149}$ I rekryteringsfrågan hade Skolöverstyrelsens förslag också uppenbarat ett vägskäl mellan olika former av maktutövning. Istället för en mer dominant och juridiskt tvingande form lade regeringens formuleringar om "andra åtgärder" grunden för en mjukare styrning som sökte uppmuntra vissa typer av handlande (val av naturvetenskap och teknik) snarare än att förbjuda andra (val av samhällsvetenskapliga och humanistiska ämnen).

Idén om individens valfrihet i relation till utbildning skulle spela en helt central roll i den specifika rationalitet för liberalt styre som tog form i samband med den tidiga efterkrigstidens rekryteringspolitik. I skriften Valfrihetens samhälle formulerade statsminister Tage Erlander 1962 de bärande visionerna för sitt parti och kontrasterade sina tankegångar mot den borgerliga oppositionens idéer. Boken var, enligt statsministern själv, den viktigaste han någonsin skrivit. I texten sökte han legitimitet för den förda politiken genom att växelvis blicka tillbaka på det gamla samhälle 
man lämnat och skåda framåt mot den ordning man önskade skulle bli verklighet. I avsnittet om utbildning gjordes tiden före kriget till en motbild. Det nyss avpolletterade parallellskolesystemet - "urvalsskolan" kallat - tjänade som främsta symbol för ett klassamhälle där olika sociala grupper hade tvingats till olika skolor. På den tiden, påpekade Erlander, var medelklassens läroverk de enda som gav behörighet till högre utbildning:

Skolreformen innebär att den gamla urvalsskolan tjänat ut. Den nya skolan medför genombrottet för en ny princip: det skall vara föräldrarna och eleverna som själva fritt väljer studieväg i grundskolan. Det är inte längre samhället som med sina trubbiga instrument skall sortera eleverna. [...] När socialdemokratin under hela 6o-talet kommer att sätta utbildningen i centrum för samhällsarbetet innebär detta att vi steg för steg vill vidga den personliga friheten på ett för varje människa avgörande område: i valet av utbildning och yrke. ${ }^{150}$

Formellt var hela boken författad av statsministern själv, men i praktiken var den i lika hög grad ett verk av Olof Palme, sedermera ecklesiastikminister och därefter Erlanders efterträdare som partiledare och regeringschef. ${ }^{151}$ Samma år som boken kom ut hade Palme debatterat grundskolan i första kammaren och uttryckt sig på ett närmast identiskt sätt om bevekelsegrunderna för den nya utbildningsformen: "En grundläggande princip för den nya skolan är det fria valet av utbildningsväg. Det är en utomordentligt tilltalande princip. Det bör inte vara samhället eller skolan, som avgör elevernas val i skolan, utan det bör vara föräldrarna och barnen."152

Att begrepp som "frihet" och "valfrihet" förekom i boken gav uttryck för en förändring av socialdemokraternas retorik efter kriget. En delvis annorlunda betoning av politikens inriktning speglade en strävan efter att ge medborgarna mer makt över sina egna liv. Borta var det marxistiskt betonade talet om klasskamp. Istället framträdde en vilja att gå vidare med samhällsbyggandet när förbättringarna av basala levnadsvillkor tycktes genomförda. ${ }^{153}$ Bokens baksidestext avslutades med en mening som sannolikt skulle ha varit otänkbar inom partiet under tidigare perioder: "Samhällets insatser bör så långt möjligt anpassas efter individernas särskilda förutsättningar och intressen för att därmed vidga de enskilda människornas valfrihet.”154

Bokens budskap kom också i sin samtid att uppfattas som en retorisk förskjutning i socialliberal riktning. Folkpartiledaren Bertil Ohlin försökte fånga situationen under sommaren 1962 genom att beskriva hur 
statsministern "stulit den liberala oppositionens kläder medan oppositionen badade". ${ }^{155}$ I Erlanders bok motsades dock denna förskjutning vid ett flertal tillfällen. Han underströk de stora skillnaderna mellan regeringens och borgerlighetens samhälleliga visioner; socialdemokratins politik skapade verklig valfrihet medan borgerligheten alltid betraktade samhällets växande inflytande som ett hot mot friheten hos individen. I själva verket var det så beskaffat, menade statsministern, att den enskilde alltid behövde det starka samhället för att främja och utöka sin frihet. Det gagnade, snarare än begränsade, individens valfrihet. Överfört till utbildningspolitiken innebar detta att den nioåriga skolplikten visserligen var ett tvång, men att den innebar en höjd kunskapsnivå vilket ökade människornas individuella handlingsutrymme. ${ }^{156}$

Under 1964 blev tankegångarna i Valfrihetens samhälle en del av lagstiftningen då de integrerades i det nya gymnasiet. Ragnar Edenman skrev i regeringens utbildningsproposition att den princip som väglett arbetet var "största möjliga frihet för den enskilda individen". ${ }^{157}$ Men vad ministern inte nämnde var att den principen i realiteten var kraftigt villkorad. Den förutsatte nämligen att skolungdomarna skulle välja naturvetenskap och teknik i en sådan utsträckning som krävdes av det moderna samhället. Detta indirekta krav illustrerades i en artikel 1957 i den socialdemokratiska idé- och debattidskriften Tiden. När Edenman bedömde utvecklingen i det kommande gymnasiet var han optimistisk och övertygad om att studentströmmarna skulle gå i önskad riktning. Han hänvisade självsäkert till "ungdomens egen förmåga att bedöma situationen på arbetsmarknaden" - bara Gymnasieutredningen såg till att prioritera de tekniska och naturvetenskapliga utbildningarna skulle eleverna förstå och förnuftigt utnyttja sitt fria val. ${ }^{158}$ Det naturvetenskapligt-tekniska valet var ur det perspektivet något rationellt och självklart, bara det tilläts verka obundet av klassamhällets begränsningar.

Samtidigt visade Edenman att en sådan övertygelse också kunde svikta. I riksdagens andra kammare 1962 var han mer försiktig i sitt framåtblickande. När han bedömde de problem som stod att vänta sammanfattades hela den problematik som senare skulle rama in rekryteringsfrågan:

Jag har sagt det förr, och jag vill upprepa det nu, att utbildningspolitikens huvudproblem under 1960-talet blir att söka uppfylla ett allt starkare krav på styrning av tillströmningen till olika utbildningsvägar och att göra detta med en så långt som möjligt bibehållen frihet för 
den enskilde att välja studieväg. Vi står här inför ett av demokratins ständiga problem: att förena frihet för den enskilde med samhällets krav på effektivitet men också med individens krav på en sysselsättning, som svarar mot erhållen utbildning. ${ }^{159}$

Under 1960-talets sista år hade denna framsynta utblick förvandlats till en realitet. Valfrihetens samhälle skulle inte kunna förverkligas på utbildningsområdet parallellt med rekryteringspolitikens målsättningar. Eleverna sökte sig inte till naturvetenskap och teknik i tillräcklig utsträckning, samtidigt som Skolöverstyrelsens förslag om hårdare styrning stred mot principen om individens rättigheter.

Situationen i Sverige påminde om den i USA ett decennium tidigare. Där hade "Sputnikchocken" visserligen skapat en stark opinion för att utbilda fler naturvetare och ingenjörer. Men samtidigt var den dominerande uppfattningen inom amerikansk debatt sedan länge att utbildning var en fråga för den enskilde. Juan Lucena beskriver skeendet utifrån Foucaults uttryck "gränserna och formerna för det sägbara" och menar att idéerna om individens frihet utgjorde diskursiva konturer för sättet på vilket styre och rekryteringspolitik kunde utövas. ${ }^{160}$ Det planmässiga system som praktiserades av Sovjetunionen - den nya fienden - utgjorde en skarp kontrast mot den egna nationella identiteten. Doktor Harry Kelly vid National Science Foundation försökte vid ett tillfälle i representanthuset att jämföra de båda länderna: "The Soviets, in planning the future of their state determine the needs for people in different professions and thereby determine the number of students in each area. In the free world, education is directed towards the development of the individual." ${ }^{161}$

En samhällsmekanism som riskerade att påminna om den ideologiska motparten var vid tidpunkten således inte möjlig. Traditionellt sett sköttes dessutom utbildningsfrågor i USA på delstatsnivå och lokala myndigheter kunde utöva starkt självbestämmande. Av skäl som underströk just dessa principer sade kongressen nej till inrättandet av ett nationellt centrum för naturvetenskapliga och tekniska utbildningar. ${ }^{162}$ De tydliga gränserna blev också utgångspunkten för hur rekryteringsfrågan utvecklades i fortsättningen. Efter hand sökte policyskaparna i Washington finna en lösning som innebar att utbildningen av naturvetare och ingenjörer kunde främjas utan att uppfattas som ett tvång och att det lokala självbestämmandet bibehölls. Resultatet blev att kongressen gav finansiellt stöd till 
National Science Foundation som sedan utformade olika program för att rekrytera fler studerande. ${ }^{163}$

Om det amerikanska motståndet mot en alltför långtgående rekryteringspolitik härrörde ur berättelsen om den fria världen i motsats till det sovjetiska tvånget, var motsvarigheten för den svenska utvecklingen snarare en egenproducerad socialdemokratisk berättelse om klassamhället. Erlander och Palme hade tecknat bilden av en nation som lyft sig ur klassorättvisor och byggt ett modernt välfärdssamhälle där alla individer - inte bara några få - valde sin egen framtid. De hade konstaterat att "den gamla urvalsskolan tjänat ut" och att samhället "med sina trubbiga instrument" inte skulle sortera eleverna. I den situationen var det inte möjligt att återinföra en hårdare styrning och riskera att upprepa en gammal ordning.

Det diskursiva gränssättandet i rekryteringspolitiken resulterade inte endast $i$ att det faktiska handlingsutrymmet beskars. Det innebar samtidigt att konturerna för den tillgängliga politiken blev tydligare. När det stod klart vad man inte kunde göra och varför, blottlades också vilka alternativ som stod till buds. Lösningarna var i både USA och Sverige tvungna att följa de spelregler som tillhandahölls av den liberala demokratins självuppfattning. Den innebar en rationalitet för liberalt styre som föreskrev att den enskildes fria val skulle upprätthållas samtidigt som ungdomarna skulle förmås att bli naturvetare och ingenjörer i den utsträckning som krävdes.

I detta kapitel har framväxten av ett nytt problemområde och dess begynnande konsekvenser behandlats. "Valfrihetens samhälle" skulle till sin praktiska utformning komma att innefatta olika former av positiv maktutövning riktad mot individer i syfte att styra dem mot vetenskap och teknik som yrke. Att motivera, uppmuntra, intressera, informera och övertyga var delar av den strategin och konkretiserade regeringens uppmaning att finna "sådana metoder som tar fasta på de faktorer som styr elevernas val". Tillvägagångssättet skulle inte begränsa sig till statliga sammanhang. Under efterkrigstiden utvecklades liknande strategier även av andra samhälleliga aktörer. I de kommande kapitlen tar jag upp utarbetandet av sådana åtgärder och program samt hur de samspelade med en snabbt ökande mängd information om skolungdomar och deras relationer till naturvetenskap och teknik. 